\title{
Effect of Biotin-Sparing Substances on Growth of Biotin- Deficient Saccharomyces cerevisiae and on the Synthesis of Nucleic Acids and Protein
}

\author{
BY FAZAL AHMAD* AND A. H. ROSE $\dagger$ \\ Microbiology Laboratory, Heriot-Watt College, Edinburgh
}

(Received 27 July 1961)

\begin{abstract}
SUMMARY
An examination was made of the ability of amino acids, purines and related compounds, and fatty acids to stimulate growth of Saccharomyces cerevisiae in biotin-deficient medium and to restore the synthesis of nucleic acids and protein. Adenine, adenosine, aspartic acid and Casamino acids (Difco) each stimulated growth to some extent and brought about a partial restoration of nucleic acid and protein synthesis. Oleic acid also stimulated growth, but the effect was much slower than that brought about by the other biotin-sparing compounds tested and it was not accompanied by a restoration of nucleic acid and protein synthesis. Stimulation of growth in biotin-deficient media supplemented with aspartic acid + oleic acid was greater than the stimulation brought about by these compounds singly. During growth of the yeast in biotin-deficient media supplemented with this or certain other mixtures of biotin-sparing compounds there was a well defined exponential phase of growth which was not apparent during growth of the yeast in unsupplemented biotindeficient medium. But the final cell crop in these supplemented media was still only about half of that obtained in biotin-optimal medium. These results are discussed in relation to the role of biotin in the synthesis of various yeast cell constituents.
\end{abstract}

\section{INTRODUCTION}

Biotin has for many years been recognized as a growth factor for microorganisms but, until recently, there has been a lack of knowledge about the fundamental role of this compound in the metabolism of living cells. Although several workers had previously obtained evidence which indicated a role for biotin in metabolic reactions involving carbon dioxide transfer (Delwiche, 1950; Lardy, Potter \& Elvehjem, 1947; Shive \& Rodgers, 1947), the coenzymic function of this compound in $\mathrm{CO}_{2}$ metabolism only became clear as a result of studies by Lynen, Knappe, Lorch, Jütting \& Ringelmann (1959) on the $\beta$-methyl-crotonyl-Co A carboxylase from a mycobacterium. It has since been reported that a biotin enzyme probably operates in other $\mathrm{CO}_{2}$-transferring reactions (Lane \& Halenz, 1960; Wakil, 1961), although not all such reactions would appear to be biotin-dependent (Hamilton \& Westheimer, 1959; Tietz \& Ochoa, 1959). Since the process of $\mathrm{CO}_{2}$ transfer is of fundamental importance in the metabolism of living cells, it is to be

* Present address, Department of Microbiology, Hahnemann Medical College, Philadelphia, Pennsylvania, U.S.A.

$\dagger$ Present address, Department of Bacteriology, University of Durham, King's College, New* castle upon Tyne. 
expected that any impairment in this process will bring about a major disturbance in cell metabolism. One result of biotin deficiency in micro-organisms is a decreased synthesis of oxaloacetate and aspartate (Shive \& Rodgers, 1947; Stokes, Larsen \& Gunness, 1947) which, in turn, is thought to be at least partly responsible for the impairment in the metabolic processes leading to synthesis of nucleic acids and protein (Ahmad, Rose \& Garg, 1961), adenosine triphosphate (ATP; Katsuki, $1959 a, b)$ and pyridine nucleotides (Rose, $1960 a, b$ ). The decline in protein synthesis under conditions of biotin deficiency presumably affects the synthesis of various enzymes, and could explain the presence in biotin-deficient organisms of diminished amounts of certain enzymes, the activities of which cannot be restored by adding biotin to cell-free preparations (Chambers \& Delwiche, 1954; Sund, Ravel \& Shive, 1958). The presint paper describes the results of experiments on the effect of various biotin-sparing compounds (including amino acids, purines and related compounds, fatty acids) on growth of biotin-deficient Saccharomyces cerevisiae and on the synthesis of nucleic acids and protein by it.

\section{ME'THODS}

Organism. The strain of Saccharomyces cerevisiae (Fleischmann) used was obtained from the Division of Applied Biology, National Research Council of Canada. Ottawa, and was maintained on slopes of malt wort agar: $10 \%(w / v)$ spray-dried malt extract ('Muntona', Munton and Fison, Itd., Stowmarket, Suffolk) $+2 \%(w / v)$ agar. Cultures wcre stored at $:^{\circ}$.

Experimental cultures. All experiments were conducted using the glucose + salts + vitamins medium ( $\mathrm{pH} \mathrm{4.5)}$ ) R Rose \& Nickerson (1956). This medium, which usually contained either an optimal $\left(8.0 \times 10^{-10} \mathrm{M}\right)$ or a suboptimal $\left(0 \cdot 4 \times 10^{-10} \mathrm{M}\right)$ concentration of D-biotin, was supplemented with various biotin-sparing substances as described later. Portions $(100 \mathrm{ml}$.) of medium were dispensed into $350 \mathrm{ml}$. conical flasks which were plugged and sterilized by autoclaving momentarily at $115^{\circ}$. The medium was inoculated by the procedure described by Rose $(1960 \mathrm{~b})$ and cultures were incubated statically at $25^{\circ}$. Growth was measured as described by Ahmad et al. (1961).

Biotin-sparing substances. With the exception of oleic acid (British Drug Houses, Ltd., Poole, Dorset) and vitamin-free Casamino acids (Difco Laboratories Inc., Detroit, Michigan, U.S.A.), all of the substances tested for biotin-sparing activity were supplied by L. Light and Co. Ltd., Colnbrook, Buckinghamshire. Each consignment was screened for possible contamination with biotin by examining the ability of the substance to stinulate growth of the biotin-requiring strain of Saccharomyces cerevisiae in biotin free medium. Each substance was tested in this way at concentrations exceeding the maximum at which it was to be incorporated into experimental media; batches which were found to be contaminated were rejected. Biotin-sparing substances were incorporated into media as solutions (pH 4.5). Oleic acid was added as a solution in $95 \%(\mathrm{w} / \mathrm{v})$ ethanol in water; the concentration of ethanol in media never exceeded $0.1 \%(\mathrm{w} / \mathrm{v})$. Gas chromatographic examination of the sample of oleic acid used showed it to contain $76 \%(\mathrm{w} / \mathrm{w})$ oleic acid, the principal contarninant being the trans isomer of oleic acid, elaidic acid $(22 \% \mathrm{w} / \mathrm{w})$; concentrations of oleic acid in media are expressed in $\mu \mathrm{g} . / \mathrm{ml}$. 


\section{Analytical methods}

Nucleic acids. Deoxyribonucleic acid (DNA) and ribonucleic acid (RNA) in samples (equiv. $3 \mathrm{mg}$. dry wt.) of yeast that had been washed three times with $\mathrm{M} / 15 \mathrm{KH}_{2} \mathrm{PO}_{4}(\mathrm{pH} 4 \cdot 5)$ were determined by the procedures described by Ahmad et al. (1961). Before DNA and RNA were estimated, acid-soluble ultraviolet (u.v.)absorbing substances were removed by extracting the yeast with $5 \mathrm{ml} .5 \%(\mathrm{w} / \mathrm{v})$ trichloroacetic acid at $3^{\circ}$ for $5 \mathrm{~min}$. This extract was made up to $\mathbf{5 . 0} \mathrm{ml}$. with $5 \%$ trichloroacetic acid and the optical density of the solution at $260 \mathrm{~m} \mu$ was taken as a measure of the acid-soluble u.v.-absorbing substances in the yeast. DNA contents were expressed as the optical density at $260 \mathrm{~m} \mu$ of an extract made up to $3 \cdot 0 \mathrm{ml}$. with $\mathrm{N}-\mathrm{HClO}_{4}$. RNA contents were also expressed as optical density at $260 \mathrm{~m} \mu$, except that the volume of extract was made up to $10 \cdot 0 \mathrm{ml}$. with $0 \cdot 2 \mathrm{~N}-\mathrm{HClO}_{4}$. All optical density measurements were made with a Unicam S.P. 500 quartz spectrophotometer, with blanks of the appropriate extracting solutions.

Protein in the residue remaining after nucleic acids and related substances had been extracted from the yeast was estimated by the micro-Kjeldahl method (Markham, 1942), with a mercuric oxide catalyst (Miller \& Houghton, 1945). Protein contents are expressed as $\mu$ g. Kjeldahl nitrogen/mg. dry wt. yeast.

Intracellular amino acid pools. Water-soluble ninhydrin-positive substances were extracted from the yeast by suspending the equivalent of $10 \mathrm{mg}$. dry wt. of washed organisms in $10 \mathrm{ml}$. water and holding this suspension for $10 \mathrm{~min}$. in an oil bath at $140-150^{\circ}$. On cooling, the supernatant fluid (about $3.5 \mathrm{ml}$.) was removed by centrifugation and, after being supplemented with washings $(2 \cdot 0 \mathrm{ml}$.) from the cell debris, was made up to $10.0 \mathrm{ml}$. with water. The content of ninhydrin-positive substances in these extracts was determined by a modification of the method of Smith \& Agiza (1957; Hagen \& Rose, 1962). Optical density measurements were related to $\mu \mathrm{g}$. amino group $\left(\mathrm{NH}_{2}\right)$ by a standard curve prepared by using purified glycine. Results are expressed as $\mu \mathrm{g}$. $\mathrm{NH}_{2} / 10 \mathrm{mg}$. dry wt. yeast.

Acid-labile phosphate pools. The acid-labile phosphate content of the yeast was determined on acetone-dried powders. These powders were prepared by harvesting yeast from cultures and washing the organisms three times with ice-cold water and then three times with ice-cold acetone (A.R.). The yeast was then spread out on a

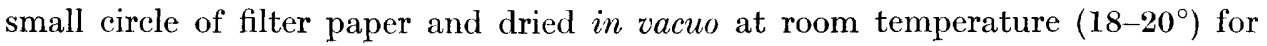
1-2 hr. Acetone-dried powders prepared in this way were found to contain $86-88 \%$ dry wt.

For the determination of acid-labile phosphate, duplicate portions (equiv 20$30 \mathrm{mg}$. dry wt.) of freshly prepared acetone-dried powder were weighed into $15 \mathrm{ml}$. tapered centrifuge tubes and treated with $2.0 \mathrm{ml}$. boiling water. The tubes were immediately placed into a boiling water bath, and a further $2.0 \mathrm{ml}$. boiling water added to each tube. After the tubes had been kept in the boiling water bath for $10 \mathrm{~min}$., they were cooled and centrifuged, the supernatant fluids removed and each made up to $5.0 \mathrm{ml}$. The content of acid-labile phosphate in portions $(2.0 \mathrm{ml}$.) of this extract ( $\mathrm{pH} 6.8$ ) was then determined, using a modification of the Fiske \& Subbakow method (Bowen \& Kerwin, 1956). The procedure used deviated from the published method principally in that a $4 \%(\mathrm{w} / \mathrm{v})$ solution of ammonium molybdate was used. After addition of the reducing agent, the volumes were made up to 
$25 \mathrm{ml}$. and the solutions allowed to stand at room temperature $\left(18-20^{\circ}\right)$ for $30 \mathrm{~min}$. The optical densities of the solutions were then measured in the Hilger 'Spekker' absorptiometer at $660 \mathrm{~m} \mu$, with a water blank. Optical density readings were related to phosphorus content by a standard curve prepared by using a solution of $\mathrm{KH}_{2} \mathrm{PO}_{4}$ (A.R.). Results are expressed as $\mu$ mole $\mathrm{P} / 100 \mathrm{mg}$. dry wt. yeast.

\section{RESULTS}

Survey of the biotin-sparing activity of various substances

Initially a survey was made of the biotin-sparing activity of a number of substances (including amino acids, purines and related compounds, fatty acids) the biosyntheses of which are known to be biotin-dependent. The growth-promoting action of each of these substances, with the exception of oleic acid, was found to be complete after incubation for about $120 \mathrm{hr}$.; analyses of nucleic acids, protein and related substances were thereforc made on yeast from $120 \mathrm{hr}$. cultures. An examination was made of the ability of each substance to spare the growth-promoting action of biotin for Saccharomyces cerevisiae and also to restore synthesis of nucleic acids and protein.

Amino acids. Aspartic acid was the first compound reported to be capable of sparing the growth-promoting action of biotin when Koser, Wright \& Dorfman (1942) showed that this amino acid was able partially to obviate the biotin requirement of Torula cremoris (Candida pseudotropicalis). Aspartic acid, and, to a lesser extent, other amino acids have since been reported to spare the biotin requirement of other micro-organisms including Saccharomyces cerevisiae (Moat \& Emmons, 1954). The effect of L-aspartic acid concentration on growth of, and synthesis of nucleic acids and protein by, $S$. cerevisiae in biotin-deficient medium is shown in Fig. 1. There was only a slight stimulation of growth in media supplemented with aspartic acid (Rose, $1960 \mathrm{~b}$ ). Nevertheless, the increase in RNA content of yeast grown in biotin-deficient media containing more than $1.0 \times 10^{-3} \mathrm{M}$ aspartic acid was appreciable, and there was also a rise in the protein and DNA contents. This increased synthesis of high molecular weight cell constituents was accompanied by a depletion of the intracellular pools of amino acids, acid-soluble u.v.-absorbing substances and acid-labile phosphate. Yeast grown in biotin-deficient media containing more than $1.0 \times 10^{-3} \mathrm{M}$ aspartic acid was coloured creamy-white instead of the pink colour that is characteristic of biotin-deficient yeast (Chamberlain, Cutts \& Rainbow, 1952), and also yrew in the form of large aggregates of organisms (Dunwell, Ahmad \& Rose, 1961).

When biotin-deficient medium was supplemented with Casamino acids up to $\mathbf{2} \cdot \mathbf{0} \mathrm{mg} . / \mathrm{ml}$, there was a greater stimulation of growth than in media supplemented with only aspartate (Fig. 2). The elfect of this mixture of amino acids on the DNA and RNA contents of the yeast was similar to that observed in biotin-deficient media supplemented with aspartic acid alone; there was, however, a somewhat greater increase in the protein content of yeast grown in biotin-deficient media supplemented with Casamino acids. Yeast grown in media containing more than $1.0 \mathrm{mg} . / \mathrm{ml}$. Casamino acids was coloured creamy-white.

Purines and related compounds. Chamberlain \& Rainbow (1954) first reported that adenine was able to spare partially the growth-promoting action of biotin on 


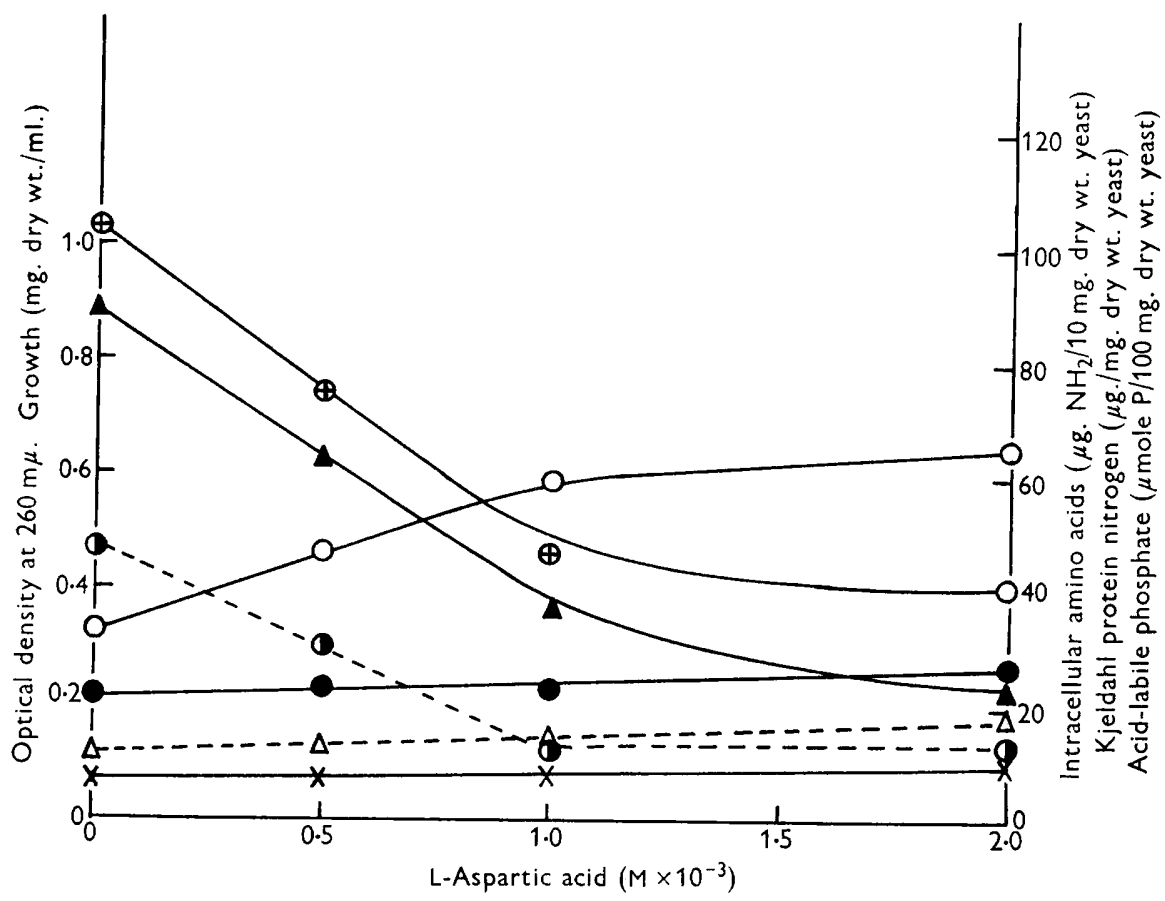

Fig. 1

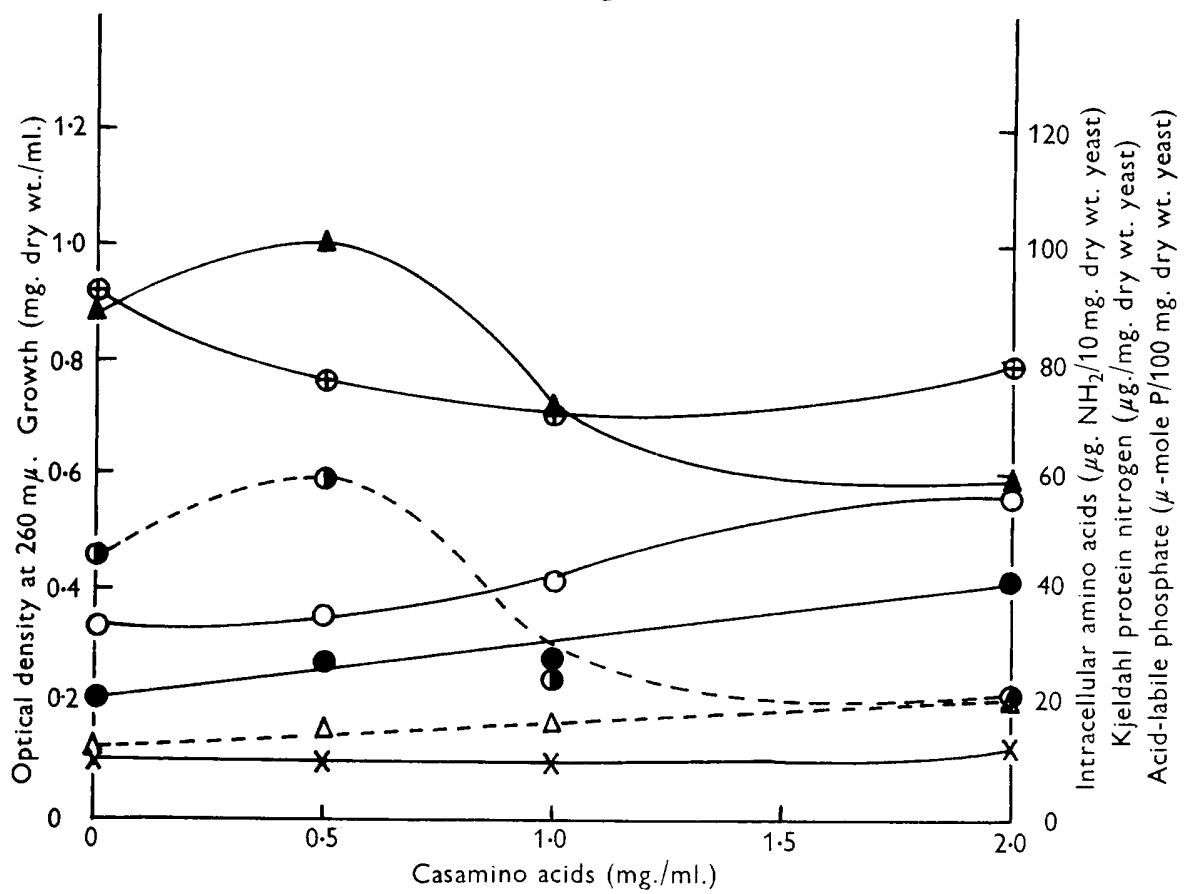

Fig. 2

Figs. 1, 2. Effect of L-aspartic acid concentration (Fig. 1) and Casamino acid concentration (Fig. 2) on growth (- - mg. dry wt./ml.) of, and contents of DNA $(\times--\times)$, RNA ( $\bigcirc-\bigcirc)$, acid-soluble u.v. absorbing substances $\left({ }_{-\infty}\right)$, Kjeldahl protein nitrogen $\left(\triangle---\triangle, \mu \mathrm{g} . / \mathrm{mg}\right.$. dry wt.), intracellular amino acids $\left(\Delta-\Delta, \mu \mathrm{g}\right.$. $\mathbf{N H}_{2} / 10 \mathrm{mg}$. dry wt.), and acid-labile phosphate $(\oplus-\oplus, \mu$ mole $\mathbf{P} / 100 \mathrm{mg}$. dry wt.) in, yeast grown in media containing a suboptimal $\left(0 \cdot 4 \times 10^{-10} \mathrm{M}\right)$ concentration of biotin. Yeast was harvested from cultures after $120 \mathrm{hr}$. at $25^{\circ}$. Contents of DNA, RNA and acid-soluble u.v.-absorbing substances are expressed as the optical densities at $260 \mathrm{~m} \mu$ of extracts from the yeast made up to $3 \cdot 0,10 \cdot 0$ and $5 \cdot 0 \mathrm{ml}$. respectively. 
Saccharomyces cerevisiae. Under the conditions used in the present work (low concentration of biotin in the medium and use of a small biotin-deficient inoculum), the growth-promoting action ol this purine was very slight (Fig. 3). Yeast grown in biotin-deficient medium containing up to $0.5 \times 10^{-3} \mathrm{M}$ adenine contained slightly increased amounts of RNA and protein as compared with yeast grown in unsupplemented biotin-deficient mediurı. These changes were accompanied by a decrease in the content of acid-soluble u.v.-absorbing substances and a rise in the contents of intracellular amino acids and acid-labile phosphate in the yeast. The DNA content of yeast grown in adenine-containing biotin-deficient media remained unchanged. Formation of pink pigment was suppressed in yeast grown in media containing more than $0.25 \times 10^{-3} \mathrm{M}$-adenine (Chamberlain \& Rainbow, 1954).

The purine guanine and the pyrimidines cytosine, thymine and uracil were found not to affect growth or colour of, or the contents of nucleic acids and protein in, biotin-deficient yeast. Each of the pyrmidines was incorporated in biotin-deficient medium in concentrations up to $1.0 \times 10^{-3} \mathrm{M}$; because of its relative insolubility, guanine was tested only up to $0 \cdot 6 \times 10^{-3} \mathrm{M}$. Adenosine was the only one of the nucleosides tested which had any effect on growth of, or content of nucleic acids and protein in, biotin-deficient yeast (Fig. 4). Stimulation of growth was greatest in media containing $\mathbf{2 \cdot 0} \times 10^{-3} \mathrm{M}$-adenosine. There was an increase in the RNA content in yeast grown in media containing $0 \cdot 5 \times 10^{-3} \mathrm{M}$-adenosine as compared with the content in yeast grown in unsupplemented biotin-deficient medium, but higher concentrations $\left(4.0 \times 10^{-3} \mathrm{M}\right)$ were required to bring about an appreciable increase in the protein content. These increases in nucleic acid and protein content were accompanied by a decline in the amounts of intracellular amino acids and acid-soluble u.v.-absorbing substances; however, in the presence of higher concentrations $\left(2 \cdot 0-4 \cdot 0 \times 10^{-3} \mathrm{M}\right)$ of adenosine, the amounts of these low molecular weight substances in the yeast increased. Growth in adenosine-containing biotin-deficient media had no detectable effect on the DNA content of the yeast. Although adenosine was capable of stimulating growth and synthesis of RNA and protein, yeast grown in biotin-deficient media containing up to $4 \cdot 0 \times 10^{-3} \mathrm{M}$ of adenosine remained pink in colour.

There was no stimulation of yeast growth in biotin-deficient media supplemented with a mixture of adenine $\left(0.5\right.$ or $\left.1.0 \times 10^{-3} \mathrm{M}\right)$ and D-ribose $\left(1.0\right.$ or $\left.2.0 \times 10^{-3} \mathrm{M}\right)$ and the nucleic acid and protein content of yeast grown in these media was the same as in yeast grown in unsupplemented biotin-deficient medium.

The only nucleotide tested for biotin-sparing activity was adenosine-2(3')phosphate (yeast adenylic acid). It was found, however, that, when this compound was incorporated into biotin-deficient medium to $2 \cdot 0 \times 10^{-3} \mathrm{M}$, there was no detectable effect on growth or colour ol, or on the contents of nucleic acids and protein in, the yeast.

Fatty acids. The ability of olvic acid to spare the growth-promoting action of biotin was first reported for Lact،bacillus casei by Williams \& Fieger (1946). Elaidic acid, which was present in the sample of oleic acid used here, has also been shown to have biotin-sparing action for" some micro-organisms (Cheng, Greenberg, Deuel $\&$ Melnick, 1951), as have certair other unsaturated fatty acids which have a chain length of 12 or more carbon atons (Hoffmann, O'Leary, Yoho, \& Liu, 1959).

When oleic acid (containing 2: \% elaidic acid), in concentrations up to $100 \mu \mathrm{g} . /$ ml. was included in biotin-deficient medium, there was a stimulation of yeast 


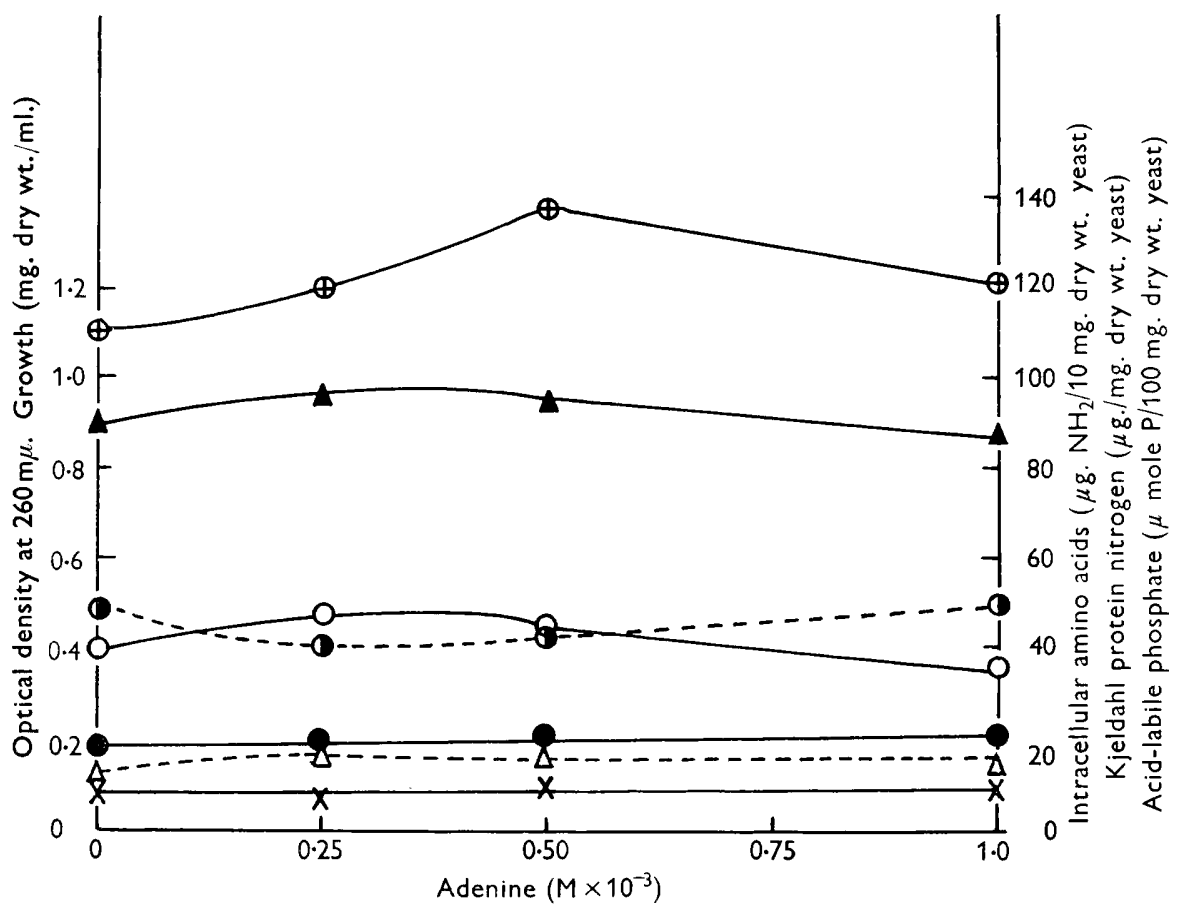

Fig. 3

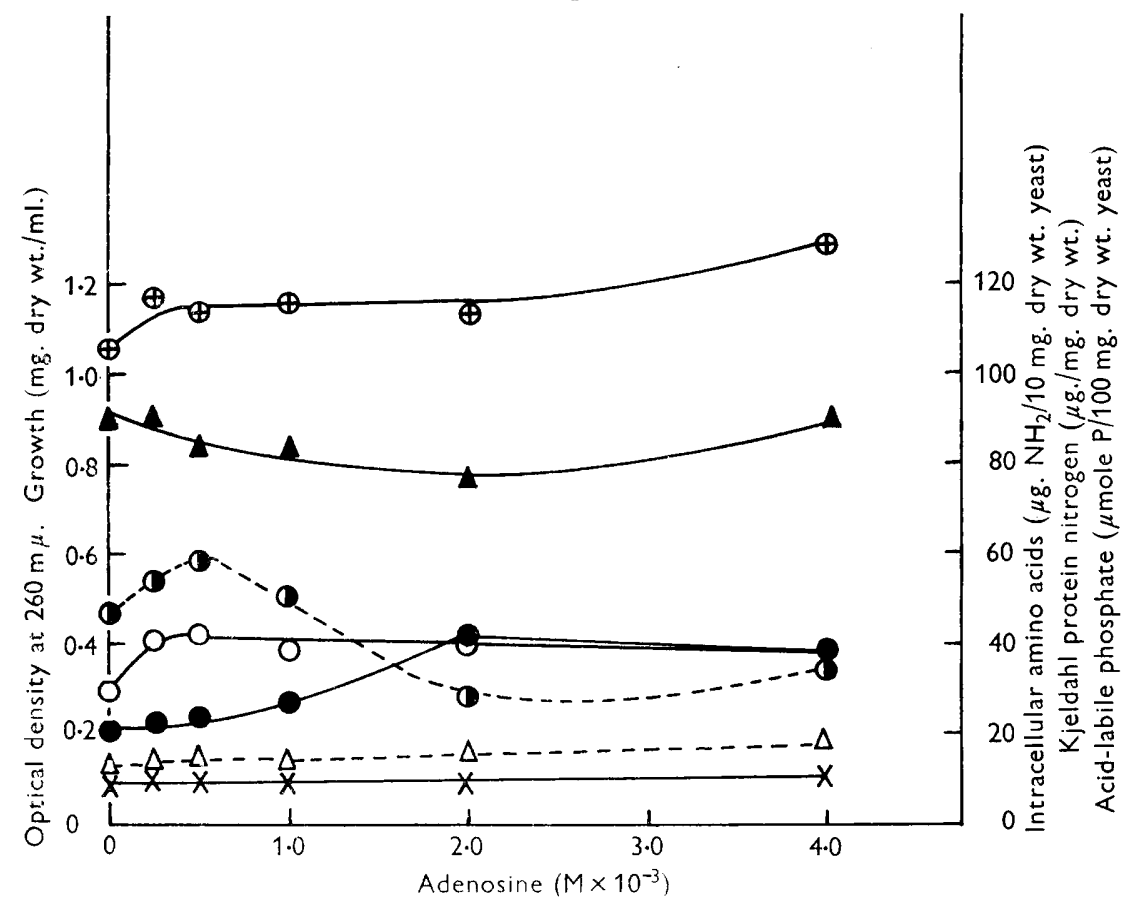

Fig. 4

Figs. 3, 4. Effect of adenine concentration (Fig. 3) and adenosine concentration (Fig. 4) on growth (-- mg. dry wt./ml.) of, and contents of DNA $(\times-x)$, RNA (O-O), acid soluble u.v.-absorbing substances $(---()$, Kjeldahl protein nitrogen $(\triangle---\triangle, \mu \mathrm{g} . /$ mg. dry wt), intracellular amino acids $\left(\Delta-\Delta, \mu \mathrm{g} . \mathrm{NH}_{2} / 10 \mathrm{mg}\right.$. dry wt.), and acidlabile phosphate $(\oplus-\oplus, \mu$ mole $\mathbf{P} / 100 \mathrm{mg}$. dry wt.) in, yeast grown in media containing a suboptimal $\left(0 \cdot 4 \times 10^{-10} \mathrm{M}\right)$ concentration of biotin. Yeast was harvested from cultures after $120 \mathrm{hr}$, at $25^{\circ}$. Contents of DNA, RNA and acid-soluble u.v-absorbing substances are expressed as the optical densities at $260 \mathrm{~m} \mu$ of extracts from the yeast made up to $3 \cdot 0,10 \cdot 0$ and $5 \cdot 0 \mathrm{ml}$. respectively. 
growth which continued as cultures were incubated for longer periods and only levelled off after about $250 \mathrm{hr}$. incubation (Fig. 5). Prolonged incubation was shown to be accompanied by a slight fall in the contents of RNA and protein in the yeast and a depletion of the pools of intracellular acid-soluble u.v.-absorbing substances and amino acids. There was, however, no detectable change in the DNA content of yeast grown in biotin-deficient media supplemented with oleic acid and the yeast remained pink in colour.

\section{Effect of mixtures on biotin-sparing substances}

From the results reported in the previous section, it was apparent that adenine, adenosine, aspartic and Casamino acids were each capable of sparing the growthpromoting action of biotin to some extent and, with the exception of oleic acid, of partially restoring synthesis of nucleic acids and protein. A study was then made

Table 1. Effect of mixtures on biotin-sparing substances of growth of, and contents of nucleic acids and protein in, biotin-deficient Saccharomyces cerevisiae

Abbreviations: AD, adenine; AN, adenosine; AS, L-aspartic acid; CA, Casamino acids; OL, oleic acid. Biotin-sparing substances were incorporated into biotin-deficient medium at the following concentrations: adenine $\left(1.0 \times 10^{-3} \mathrm{M}\right)$, adenosine $\left(1.0 \times 10^{-3} \mathrm{M}\right)$, L-aspartic acid $\left(2.0 \times 10^{-3} \mathrm{M}\right)$, Casamino acids $(2 \mathrm{mg} \cdot / \mathrm{ml}$.$) , oleic acid (100 \mu \mathrm{g} . / \mathrm{ml}$.$) .$ Cultures were removed after $120 \mathrm{hr}$. at $25^{\circ}$ and, after growth had been measured, the yeast was harvested, washed and analysed.

\begin{tabular}{|c|c|c|c|c|}
\hline \multirow[b]{2}{*}{$\begin{array}{l}\text { Additions to } \\
\text { biotin-deficient } \\
\text { medium }\end{array}$} & \multirow[b]{2}{*}{$\begin{array}{l}\text { Growth } \\
\text { (mg. dry wt. } \\
\text { ml.) }\end{array}$} & \multicolumn{3}{|c|}{ Content of } \\
\hline & & \multicolumn{2}{|c|}{$\begin{array}{c}\text { (Optical density } \\
\text { at } 260 \mathrm{~m} \mu \text { ) }\end{array}$} & $\begin{array}{l}\text { Kjeldahl protein } \\
\text { nitrogen } \\
\text { ( } \mu \mathrm{g} . / \mathrm{mg} . \\
\text { dry wt.) }\end{array}$ \\
\hline None & $0 \cdot 21$ & $0 \cdot 09$ & 0.32 & $14 \cdot 2$ \\
\hline AD & 0.22 & 0.08 & $0 \cdot 37$ & $14 \cdot 9$ \\
\hline $\mathbf{A N}$ & $0 \cdot 27$ & 0.09 & $0 \cdot 38$ & $14 \cdot 8$ \\
\hline AS & $0 \cdot 29$ & $0 \cdot 11$ & $0 \cdot 65$ & 18.9 \\
\hline CA & 0.42 & $0 \cdot 13$ & 0.56 & $21 \cdot 7$ \\
\hline OL & $0 \cdot 34$ & $0 \cdot 12$ & 0.32 & $15 \cdot 6$ \\
\hline $\mathrm{AD}+\mathrm{CA}$ & $0 \cdot 3 r$ & $0 \cdot 16$ & $0 \cdot 65$ & $22 \cdot 4$ \\
\hline $\mathbf{A N}+\mathbf{C A}$ & 0.46 & 0.09 & 0.55 & $17 \cdot 0$ \\
\hline $\mathrm{CA}+\mathrm{OL}$ & 0.56 & $0 \cdot 14$ & 0.57 & $19 \cdot 8$ \\
\hline $\mathbf{A S}+\mathbf{O L}$ & $0 \cdot 56$ & $0 \cdot 15$ & 0.53 & $19 \cdot 0$ \\
\hline $\mathrm{AD}+\mathrm{OL}$ & $0 \cdot 36$ & 0.08 & 0.38 & $13 \cdot 8$ \\
\hline $\mathbf{A N}+\mathbf{A S}$ & $\mathbf{0} \cdot \mathbf{3 4}$ & $\mathbf{0} \cdot 13$ & $0 \cdot 73$ & $23 \cdot 8$ \\
\hline $\mathrm{AN}+\mathrm{OL}$ & $0 \cdot 39$ & 0.09 & $0 \cdot 29$ & $13 \cdot 0$ \\
\hline $\mathrm{AN}+\mathbf{A S}+\mathrm{OL}$ & $0 \cdot 62$ & $0 \cdot 14$ & 0.50 & $15 \cdot 4$ \\
\hline $\mathrm{AN}+\mathrm{CA}+\mathrm{OL}$ & $0 \cdot 62$ & $0 \cdot 19$ & $0 \cdot 58$ & $21 \cdot 6$ \\
\hline $\mathrm{AS}+\mathrm{CA}+\mathrm{OL}$ & 0.55 & $0 \cdot 17$ & 0.73 & $20 \cdot 8$ \\
\hline
\end{tabular}

of the effect of certain binary and tertiary mixtures of these biotin-sparing substances on growth of, and synthesis of nucleic acids and protein by, the biotindeficient yeast, in order to discover whether there exist synergistic relationships among the actions of these substances. The results of this study are summarized in Table 1. The growth-promoting effect of most of the mixtures tested was approximately additive. But the increase in growth in media supplemented with oleic acid + aspartic acid was appreciably greater than the sum of the increases obtained when each of these compounds was present singly in the medium. This synergistic 


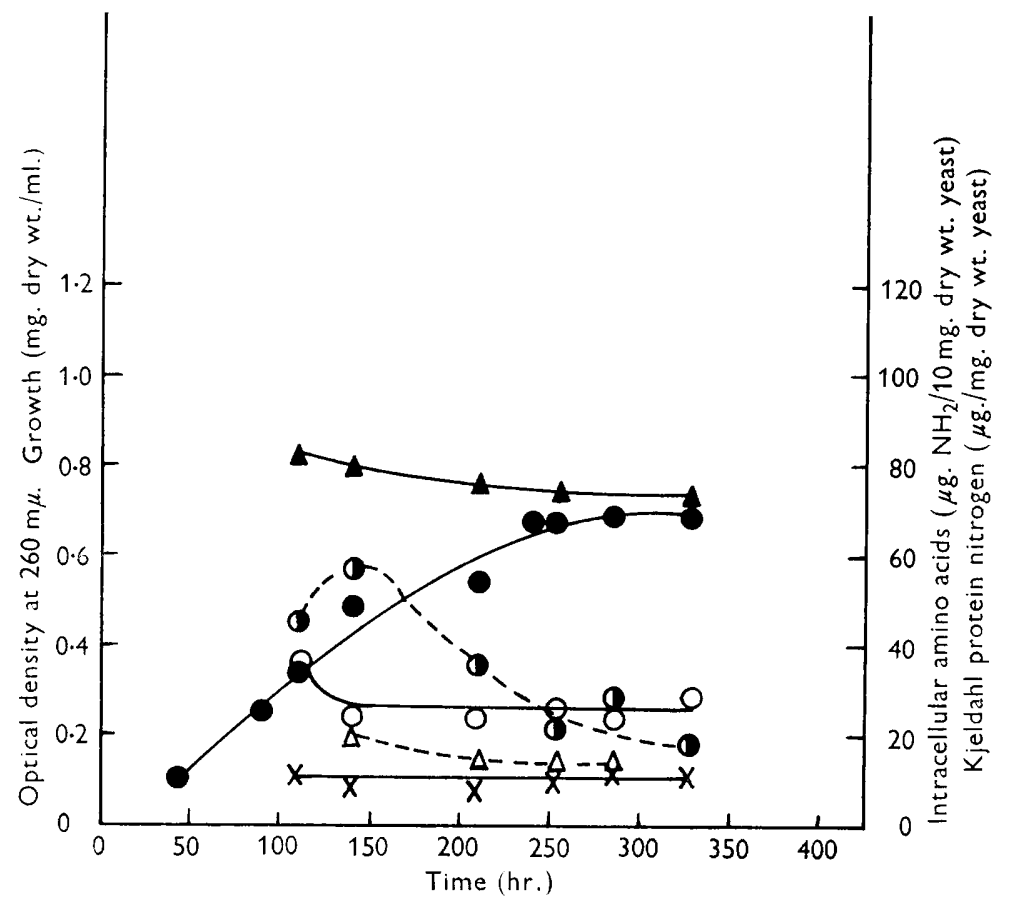

Fig. 5

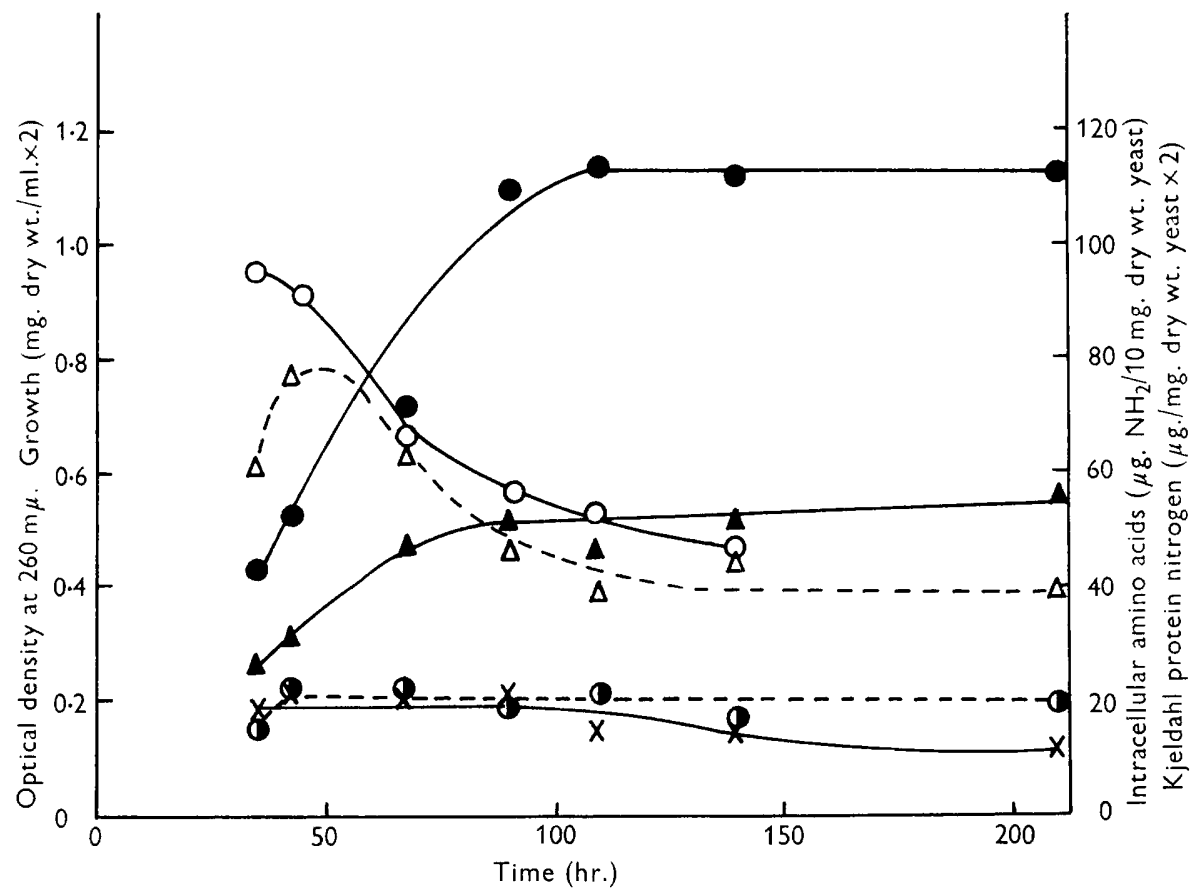

Fig. 6

Figs. 5, 6. Effect of incubation time on growth (-- mg. dry wt./ml.) of, and contents of DNA $(\times-\times)$, RNA $(\bigcirc-\bigcirc)$, acid-soluble u.v. -absorbing substances $(O---()$, Kjeldahl protein nitrogen $(\triangle---\triangle, \mu \mathrm{g} . / \mathrm{mg}$. dry wt.), and intracellular amino acids ( $\Delta-\Lambda, \mu \mathrm{g}$. $\mathrm{NH}_{2} / 10 \mathrm{mg}$. dry wt.) in, yeast grown in a medium containing a suboptimal concentration $\left(0.4 \times 10^{-10} \mathrm{M}\right)$ of biotin and supplemented with oleic acid $(100 \mu \mathrm{g} . / \mathrm{ml}$; Fig. 5) or L-aspartic acid $\left(2 \cdot 0 \times 10^{-3} \mathrm{M}\right)+$ oleic acid $(100 \mu \mathrm{g} . / \mathrm{ml}$; Fig. 6$)$. Contents of DNA, RNA and acid-soluble u.v.-absorbing substances are expressed as the optical densities at $260 \mathrm{~m} \mu$ of extracts from the yeast made up to $3 \cdot 0,10 \cdot 0$ and $5 \cdot 0 \mathrm{ml}$. respectively. 
effect was also observed in biotin-deficient medium supplemented with adenosine + aspartic acid + oleic acid, although the magnitude of the effect was approximately the same as in medium supplemented with aspartic acid +oleic acid. Yeast grown in biotin-deficient media containing aspartic acid, in the presence or absence of other biotin-sparing substances, grew in the form of large aggregates of cells (Dunwell et al. 1961).

\section{Growth of the yeast in media containing mixtures of certain biotin-sparing substances}

It was apparent from the data presented in Table 1 that growth of, and synthesis of nucleic acids and protein by, biotin-deficient Saccharomyces cerevisiae was restored, to an appreciable extent, by mixtures of certain biotin-sparing substances.

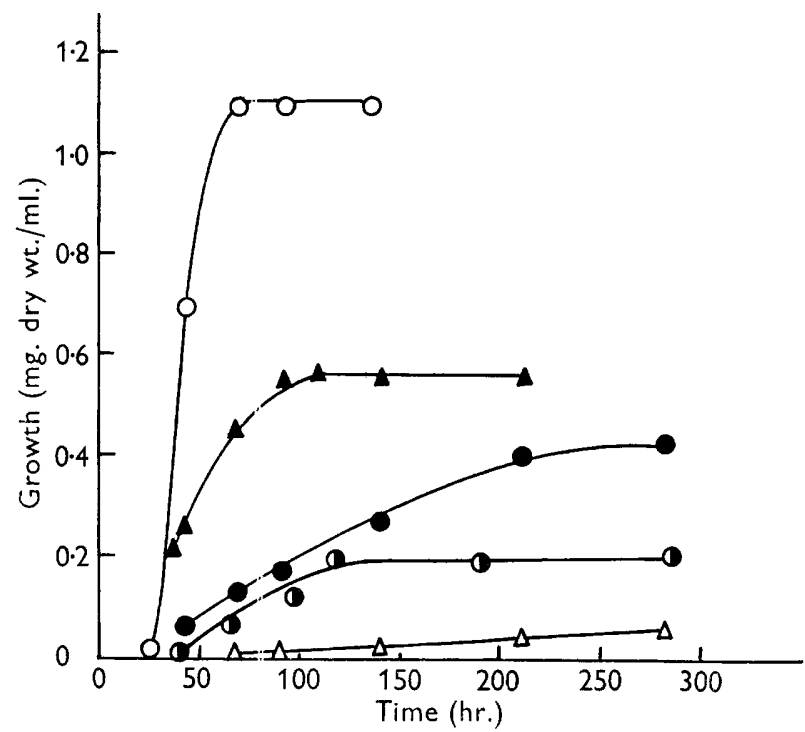

Fig. 7. Effect of incubation time on growth of the yeast in media containing an optimal $\left(8.0 \times 10^{-10} \mathrm{M}\right)$ concentration of biotin $(\mathrm{O}-\mathrm{O})$, a suboptimal $\left(0.4 \times 10^{-10} \mathrm{M}\right)$ concentration of biotin (-), and a subsptimal concentration of biotin but supplemented with L-aspartic acid $\left(2 \cdot 0 \times 10^{-3} \mathrm{M}\right)+$ ol: ic acid $(100 \mu \mathrm{g} . / \mathrm{ml}$. $)(\mathbf{\Delta}-\mathbf{\Delta})$. Curves showing growth in biotin-free medium $(\triangle-\triangle)$ ard in biotin-free medium supplemented with $\mathrm{L}$-aspartic acid $\left(2 \cdot 0 \times 10^{-3} \mathrm{M}\right)+$ oleic acid $(100 \mu \mathrm{g} \cdot / \mathrm{ml}).(\circlearrowleft-\mathrm{O})$ are also shown.

But biotin-deficient yeast differs from that grown under biotin-optimal conditions not only in containing diminished amounts of nucleic acids and protein but also in that, during the growth cycle, it does not show the same sequence of changes in nucleic acid and protein conten (Ahmad et al. 1961). Experiments were therefore conducted to discover whether the increased synthesis of nucleic acids and protein in yeast grown in media containing mixtures of certain biotin-sparing substances was accompanied by changes in the amounts of these constituents similar to those which occur in biotin-optimal grown yeast. The data in Fig. 6 show that, in yeast grown in biotin-deficient mediurn supplemented with aspartic acid + oleic acid, the pattern of changes in the RNA and protein contents was qualitatively similar to that which occurs during growth of biotin-optimal yeast (Ahmad et al. 1961). 
During the early part of the exponential phase of growth, the protein content of the yeast was almost equal to that in early exponential phase biotin-optimal yeast. In these cultures, there was, moreover, a well defined exponential phase of growth, followed by a stationary phase; these phases of growth were less well defined in cultures of the yeast grown in unsupplemented biotin-deficient medium (Fig. 7).

Although mixtures of certain biotin-sparing substances brought about a very appreciable restoration of nucleic acid and protein synthesis, the crop in stationary phase cultures of the yeast grown in these media was still only about half of that in stationary phase biotin-optimal cultures. Also, the amount of growth in biotinfree medium containing aspartic acid + oleic acid was still only a small fraction of the amount in stationary phase biotin-optimal cultures (Fig. 7).

\section{DISCUSSION}

It would seem, from the results obtained in this study, that the biotin-sparing action of oleic acid ( $+22 \%$ elaidic acid) is fundamentally different from the effect brought about by amino acids, adenine and adenosine. Thus, the growth-promoting effect of oleic + elaidic acid was much slower than that evoked by the other biotinsparing substances, and it was not accompanied by an increased synthesis of nucleic acids and protein. A further difference between the biotin-sparing action of the oleic acid and that of the other substances tested (with the exception of adenosine) was that yeast grown in medium supplemented with the oleic acid remained pink in colour whereas the presence of adenine, aspartic acid or Casamino acids in biotindeficient medium suppressed the formation of pink pigment. The chemical nature of this pink pigment is not known, but its accumulation has been reported to be associated with an impairment in the metabolic processes leading to purine synthesis (Chamberlain et al. 1952). This supported the finding that, in yeast grown in biotindeficient medium containing oleic acid, there was no appreciable restoration of purine synthesis. Further evidence to support the suggestion that the biotin-sparing action of oleic acid differs from that of the other substances tested comes from the discovery of a synergistic action in the ability of a mixture of aspartic acid and oleic acid to spare the growth-promoting action of biotin. The marked biotin-sparing action of a mixture of aspartic acid and oleic acid was noted by Potter \& Elvehjem (1948), who reported that this mixture of compounds could almost completely replace biotin in the nutrition of Lactobacillus arabinosus.

Previous workers (Chamberlain et al. 1952; Chamberlain \& Rainbow, 1954; Moat, Wilkins \& Friedman, 1956) have suggested that the biotin-sparing action of aspartic acid is explained largely by its ability to restore purine synthesis, the amino acid functioning both in the synthesis of inosinic acid (Wahba \& Shive, 1954) and in amino group transfer within the purine skeleton (Abrams \& Bentley, 1955). The data reported in the present paper substantially support this view for, in yeast grown in media containing either aspartic acid alone or Casamino acids, there was a marked increase in the RNA content as compared with yeast grown in amino acidfree medium. The finding that Casamino acids had a greater stimulatory effect on protein synthesis by, and growth of, the yeast, as compared with aspartic acid alone, suggests that, although aspartic acid can bring about a substantial restoration of RNA synthesis, it is necessary to provide the organisms with additional exogenous 
amino acids for this increased RNA synthesis to lead to synthesis of more protein. Thus, the intracellular amino acid pool in yeast grown in biotin-deficient medium supplemented with aspartic acid alone decreased to a very low value. This could be explained by an inability of the biotin-deficient yeast to synthesize other amino acids from aspartic acid, for biotin has been reported to be essential in certain transamination reactions (Lichstein \& Umbreit, 1947; Lichstein \& Christman, 1948; Nadkarni \& Sreenivasan, 1957).

The biotin-sparing action of adenine and adenosine would also seem to depend upon their ability to circumvent the metabolic lesions in purine synthesis induced by biotin deficiency, although there is apparently a biochemical difference between the actions of these two compounds since adenine, but not adenosine, suppressed formation of pink pigment by the yeast.

Biotin is known to be essential for the synthesis of fatty acids, and a coenzymic role for this compound in the carboxylation of acetyl CoA during fatty acid synthesis has recently been demonstrated (Wakil, 1961). Saccharomyces cerevisiae contains about $4 \%$ by weight of lipid (Newman \& Anderson, 1933) and, since it is likely that most of this lipid exists in the form of membranes, biotin-deficient yeast, which is apparently unable to synthesize certain fatty acids, must contain less membranous material as compared with biotin-op timal yeast. The effects of this shortage of membranous material on the biochemical organization of the yeast cell must be profound. It could mean that additional protein synthesized by organisms in biotin-deficient media containing adenine, adenosine or amino acids cannot become functional because of a lack of suitable membranes on which certain of these enzymes become oriented. Such a type of intracellular derangement under conditions of biotin deficiency might explain the role that has been reported for oleic acid in the control of cell permeability in biotin-deficient micro-organisms (Traub \& Lichstein, 1956). Furthermore, it has been suggested that lipid-amino acid complexes act as intermediates in the synthesis of protein by micro-organisms (Hunter \& Goodsall, 1961). Any impairment in the lipid-synthesizing capacity of the yeast under conditions of biotin deficiency might, therefore, impose a further restriction on protein synthesis.

Even in biotin-deficient media supplemented with comparatively high concentrations of aspartic acid or Casamino acids, and oleic acid, growth of the yeast was still appreciably restricted as compared with that in biotin-optimal medium; growth in biotin-free media supplemented with either of these pairs of biotinsparing substances was even more severely restricted. Since aspartic acid and Casamino acids were each shown to be capable of restoring synthesis of RNA and total protein to an appreciable extent, it must be concluded that utilization of this protein in metabolic reactions leading to growth of the yeast is dependent upon a supply of biotin which cannot be replaced by the biotin-sparing compounds examined in this study. The nature of these particular biotin-requiring reactions is not known, but there is evidence to suggest that they may be concerned with the synthesis of yeast cell-wall constituents. Cells of Saccharomyces cerevisiae grown in biotin-deficient medium contain increased amounts of glucan and diminished amounts of mannan as compared with biotin-optimal yeast (Dunwell et al. 1961); both of these polysaccharides are known to occur in the cell walls of $S$. cerevisiae (Northcote \& Horne, 1952). The polysaccharide composition of yeast grown in 
biotin-deficient media supplemented with aspartic acid, or with aspartic acid + oleic acid, showed even greater differences in the contents of glucan and mannan and, under these conditions, the organisms grew in large aggregates (Dunwell et al. 1961). Further evidence to support the suggestion that biotin functions in the metabolism of yeast cell-wall constituents comes from the report by Nickerson (1961) that in Candida albicans biotin is concentrated in the cell-wall glucomannan-protein complex. It is perhaps significant that biotin should be associated with a cell-wall component that has been shown to be synthesized in restricted amounts under conditions of biotin deflciency.

The authors thank Dr G. D. Muir of The British Drug Houses Ltd., for help in obtaining a gas chromatographic analysis of the oleic acid used.

\section{REFERENCES}

Abrams, R. \& Bentley, M. (1955). Transformation of inosinic acid to adenylic and guanylic acids in a soluble enzyme system. J. Amer. chem. Soc. 77, 4179.

Ahmad, F., Rose, A. H. \& Garg, N. K. (1961). Effect of biotin deficiency on the synthesis of nucleic acids and protein by Saccharomyces cerevisiae. J. gen. Microbiol. 24, 69.

Bowen, W. J. \& Kerwin, T. D. (1956). A simple method for assaying adenosine triphosphate and adenosine diphosphate in mixtures. J. biol. Chem. $220,9$.

Chamberlain, N., Cutss, N. S. \& Rainbow, C. (1952). The formation of pigment and arylamine by yeasts. J. gen. Microbiol. 7,54 .

Chamberlain, N. \& Rainbow, C. (1954). The formation of diazotisable amine and hypoxanthine by yeast: possible implications in the biosynthesis of purines. J. gen. Microbiol. $11,180$.

Chambers, E. A. \& Delwiche, E. A. (1954). Biotin and succinate decarboxylation. $J$. Bact. 68, 131.

Cheng, A. L. S., Greenberg, S. M., Deuel, H. J. \& Melnick, D. (1951). Biotin-like activity of positional and stereoisomers of octadecenoic acids. J. biol. Chem. 192, 611 .

Delwiche, E. A. (1950). A biotin function in succinic acid decarboxylation by Propionibacterium pentosaceum. J. Bact. 59, 439.

Dunwell, J. L., Ahmad, F. \& Rose, A. H. (1962). Changes in the polysaccharide composition of yeast resulting from biotin deficiency. Biochim. biophys. Acta, 51, 604.

HAgen, P.-O. \& Rose, A. H. (1961). Studies on the biochemical basis of the low maximum temperature in a psychrophilic cryptococcus. J. gen. Microbiol. 27, 89.

Hammton, G. A. \& Westheimer, F. H. (1959). A crystalline decarboxylase without biotin. J. Amer. chem. Soc. 81, 2277.

Hofmann, K., O'Leary, W. M., Yoho, C. W. \& Liv, T. H. (1959). Further observations on the lipide stimulation of bacterial growth. J. biol. Chem. 234, 1672.

Hunter, G. D. \& Goodsall, R. A. (1961). Lipo-amino acid complexes from Bacillus megaterium and their possible role in protein synthesis. Biochem. J. 78, 564 .

KATSUKI, H. (1959 $a)$. Studies on the metabolic function of biotin. III. Accumulation of $\alpha$-keto acids in biotin-deficient cultures of Piricularia oryzae. J. Biochem., Tokyo, 46, 621.

KATSUKI, H. (1959b). Studies on the metabolic function of biotin. IV. Function of biotin in $\alpha$-keto acid oxidation. J. Biochem., Tokyo, 46, 979.

Koser, S. A., Wright, M. H. \& Dorfman, A. (1942). Aspartic acid as a partial substitute for the growth-promoting effect of biotin on Torula cremoris. Proc. Soc. exp. Biol., N.Y., 51, 204.

Lane, M. D. \& Halenz, D. R. (1960). Transcarboxylation and $\mathrm{CO}_{2}$ 'exchange' catalyzed by purified propionyl carboxylase. Biochem. biophys. res. Commun. 2, 436.

Lardy, H. A., Potter, R. L. \& Elvehjem, C. A. (1947). The role of biotin in bicarbonate utilization by bacteria. J. biol. Chem. 169, 451. 
Lichstein, H. C., \& Christman, J. R. (1948). The role of biotin and adenylic acid in amino acid deaminases. J. biol. Chem. 175, 649.

Lrchstein, H. C. \& Umbreit, W. W. (1947). Biotin activation of certain deaminases. J. biol. Chem. 170, 423.

Lynen, F., Knappe, J., Lorch, E., Jütring, G. \& Ringelmann, E. (1959). Die biochemische Funktion des Biotins. Angew. Chem. 71, 481.

Marкнам, R. (1942). A steam distillation apparatus suitable for micro-Kjeldahl analysis. Biochem. J. 36, 790.

Miller, L. \& Hougriron, J. A. (1945). The micro-Kjeldahl determination of the nitrogen content of amino acids and proteins. J. biol. Chem. 159, 373.

Mont, A. G. \& Emmons, E. K. (1954). The amino acid nutrition of yeasts in relationship to biotin deficiency. J. Bact. 68, 687.

Mont, A. G., Wilkins, C. N. \& Friedman, H. (1956). A role for biotin in purine biosynthesis. J. biol. Chem. 223, 985.

Nadkarni, G. B. \& Sireenivasan, A. (1957). The metabolism of serine in biotin deficiency. Proc. Indian Acad. Sci. 46, B, :229.

Newman, M. S. \& Anderson, R. J. (1933). The chemistry of the lipids of yeast. I. 'The composition of the acetone-soluble fat. J. biol. Chem. 102, 219.

Nickerson, W. J. (1961). Role of biotin in the multiplication of yeasts. Bact. Proc. p. 177.

Northcote, D. H. \& Horne, R. W. (1952). The chemical composition and structure of the yeast cell wall. Biochem. J. 51, 232.

Potter, R. L. \& Elvehjem, C. A. (1948). Biotin and the metabolism of Lactobacillus arabinosus. J. biol. Chem. 172, 531.

Rosk, A. H. $(1960 a)$. Exeretion of nicotinic acid and nicotinic acid adenine dinucleotide by biotin-deficient yeast. Nature, Lond. 186, 139.

Rose, A. H. $(1960 \mathrm{~b})$. Excretion of nicotinic acid by biotin-deficient Saccharomyces cerevisiae. J. gen. Microbiol. 23, 143.

Rose, A. H. \& Nickerson, W. J. (1956). Secretion of nicotinic acid by biotin-dependent yeasts. J. Bact. 72,324 .

Shrve, W. \& Rougers, L. L. (1947). Involvement of biotin in the biosynthesis of oxalacetic and $\alpha$-ketoglutaric acids. J. biol. Chem. 169, 453.

Smitr, A. M. \& AGrza, A. H. (1957). The determination of amino acids colorimetrically by the ninhydrin reaction. Aralyst, 76, 623 .

Stokes, J. L., Larsen, A. \& Ginness, M. (1947). Biotin and the synthesis of aspartic acid by micro-organisms. J. biol. Chem. 167, 613.

Sund, R. F., Raver, J. M. \& Shive, W. (1958). Ornithine-citrulline enzyme synthesis in biotin-deficient cells of Streptococcus lactis. J. biol. Chem. 231, 807.

Trexz, A. \& OchoA, S. (1959). Metabolism of propionic acid in animal tissues. V. Purification and properties of propionyl carboxylase. J. biol. Chem. 234, 1394.

Traub, A. \& Lichstein, H. C. (1956). Cell permeability; a factor in the biotin-oleate relationship in Lactobacillus arabinosus. Arch. Biochem. Biophys. 62, 222.

Wariba, A. J. \& Shive, W. (195*). A role of aspartic acid in purine biosynthesis. J. biol. Chem. 211, 155.

WAKIL, S. J. (1961). Mechanism of fatty acid synthesis. J. lipid Res. 2 , 1.

Wilitiams, V. R. \& Fieger, E. A. (1946). Oleic acid as a growth stimulant for Lactobacillus casei. J. biol. Chem. 166, 335. 